\title{
The Effectiveness of Students' Worksheet of Virtual Laboratory Practice on Dynamic Electricity to Improve Science Process Skill
}

\author{
Zulimah $^{1}$, Abdurrahman ${ }^{2}$, Tri Jalmo ${ }^{3}$
}

\begin{abstract}
${ }^{1}$ Master Student of Physics Science of Faculty of Teacher Training and Education of, University of Lampung Indonesia,
${ }^{2,3}$ Lecturer of Master ProgramofPhysics Science of Faculty of Teacher Training and Education of University of Lampung Indonesia,
\end{abstract}

\begin{abstract}
The purpose of this research is to produce virtual laboratory practicum students' worksheet using PhETsimulations media, which is attractive, useful, and effective to improve students' science process skill. From the potency and problemsgained from the analysis of Physics teachers' responses of Senior High Schools in Lampung Province, Indonesia, 40\% of Senior High Schools have laboratory equipment and facilities for real practicum and $80 \%$ of Physics teachers need students' worksheet despite in the virtual laboratory forms. Based on the students' need analysis, 100\%students need practicum activities. The data collecting technique used wasassessment sheet of material and media experts and questionnaires of attractiveness and usefulness of students' worksheets. The test involved 68 State and Private Senior High School Students inLampung Province, Indonesia. It was obtained that the means of pre-test result $=55$ and 44, and post-test result $=89$ and 82. The usefulness and attractivenesswere (86,4\%) attractive, (84,7\%) useful, and effectiveness with $N$-Gain (g) 0.80 and 0.75. It is considered high classification to improve students' learning achievement. The effectiveness level in improving science process skill is measured from practicum activity score, hypotheses proposal, experiments, data collecting, and conclusion drawing. The means of $\mathrm{N}$-Gain $(\mathrm{g})=0.7$, and it is considered high and effective. At the end of the practicum activity, there was a cognitive assessment of the comprehension test results of dynamic electricity concept from both schools. The means score were 89.33 and 86.67, which means that the scores have fulfilledthe minimum criteria of mastery learning (75).
\end{abstract}

Keywords - Science process skill, simulations PhET media, practice worksheet, virtual laboratory.

\section{INTRODUCTION}

Physics is a part of Natural Science subject, which is essentially a subject related to process, product, and attitude (Aly and Rahma, 2011: 18). Learning physics is not just a mastery of a collection of knowledge in the form of facts, concepts or principles, but also a process of discovery, as it is stated by West (1985: 20), "concept development is the major part of school and college learning ". Therefore, the study of physics emphasizes the provision of direct experience to develop the competence so that learners can explore and understand the natural surroundings scientifically as well as foster the ability to think, work, guess, observe, measure, investigate and communicate. "Activity-oriented learning as an approach that emphasizes the learners' activities optimally to obtain balanced learning outcomes" (Sanjaya, 2009: 179).

Science process skill is one of the teaching methods that emphasize how the lesson material is taught and learned. According to Soegeng (2000: 68) in learning the process skills, learners must be active. Learning skills cannot be separated by learning concepts. Both are continuous interconnected lines. Learning the concepts emphasize the appreciation of concepts while process skills emphasize the acquisition and understanding of facts and principles. Learning process skills is not possible if there is no material or thing to learn. Conversely, learning concepts will not occur if there is no process skill in each learner who is learning. These facts are included in developing the students' science process (SPS) skills (Zachariaet al., 2008).

One of the other important issues in physics learning is to explain the difficult concept, and difficulty in conducting trial or experiments in the laboratory as well as in the classroom. Hofstein \& Lunetta, (2003) stated that one of the factors affecting the success of laboratory activities is resources that include materials and equipment, space and furniture, laboratory staff, and technicians. In addition, not all experiments can be performed not only because there is no tool, but because of the characteristics of the experiment itself.

The fact that happened in school, physics learning in senior high schools in Lampung Provinceis less maximal in using the laboratory. This happens because of 
the limitations of laboratory equipment and materials owned by these schools. The results of the analysis of physics teachers' responses in senior high schools in Lampung Province, Indonesia, found that there was only $40 \%$ of a total number of senior high schoolswhich hascomplete laboratory tools and materials. Thus, the limitation of physics laboratory facilities is the main obstacle of science process skill in physics learning. It is because learning cannot be performed optimally, and finally, the students are lack of the ability to perform scientific process skills and scientific procedures that lead to the low students' learning outcome achievement.

Therefore, it is necessary to have a solution to help the teachers in teaching physics so that the students obtain good learning achievement and have good science process skills. One of them is virtual laboratory learning using practicum Students' Worksheet. According to Imron (2012), Virtual laboratory is a laboratory with tools and materials used for practical activities in the form of a complete set of computer with application program (software) specially designed for experimental activities. This software contains animated tools, materials and interactive design for experimental activities. Thus, the students can conduct the experiments in accordance with the worksheets that have been provided. In virtual laboratory, students can collect data quickly in any situation and conduct experiments that cannot be performed in a real laboratory in general. Virtualpracticum, according to Sutrisno (2012: 43) is that we do computer-assisted experiments that have been available in software which is ready for operation. We seem to do practicum like the real practicum in the laboratory.

Using a number of laboratory tools will greatly support students' understanding of the concept of science, this is because the concepts contained in the book are sometimes abstract and difficult to understand. A very reasonable expectation if learners want to practice in the laboratory. And from the results of questionnaire analysis also showed that teachers as much as $80 \%$ need practicum Students' Worksheets eventhoughit is onlyvirtual laboratory with interactive media such as PhET Simulation.

Various reasons are emerging when there is a desire to use the laboratory. The most common thing is the lack of equipment, the ineffectiveness of the number of tools to be used (e.g. the number of devices is limited, broken, has no power source), no laboratory staff is ready to prepare the tools and space to use on each competency will be practiced, teachers who do not provide the time to prepare thetools, practicum Students' Worksheets, do not take care of tools, and other reasons. Various research results related to the use of multimedia in learning have been conducted. The use of computer simulations can replace real equipment in simple electrical circuits (Finkelstein, et.al., 2005).

Based on the data analysis of student needs, $100 \%$ of them wanted practicum activities, although the equipment in the laboratory is inadequate. Unfortunately, not all schools provide opportunities for learners to do practicum activities. In fact, the media for virtual laboratorypracticum such as PhETSimulation uses $98 \%$ of computers in schools which isalready available. And students have the ability to operate the interactive media. Students also need practicum Students' Worksheetseventhoughit is in the form of virtual laboratoryactivity because there is only $48 \%$ practicum Students' Worksheets availability in schools.

The completeness and availability of tools and materials of real practicum in senior high schools in Lampung Provinceare still poor, that to overcome this problem, virtual laboratory activity is required (Virtual experiment). Virtual laboratory experiments uselearning simulation (software) and computers in performing the important functions of the laboratoryas well as real experiments. The advantage of virtual laboratory utilization in physics learning is to facilitate the students in obtaining information and facilitate the teacher in conveying the contextual problem. It can increase students' confidence, skills and knowledge to solve problems, and to be independent thinkers and learners. It can be seen visually and dynamically that it is a rich mental model of information which facilitates students in understanding the concept, especially abstract and process concepts.

The utilization of virtual laboratory is expected to increase the activity of learners. The results of Finkelstein's research, et.al., (2005) showed that welldesigned simulations used in appropriate contexts can be more effective educational tools than real laboratory equipment in developing conceptual understanding of students.

According to Sutrisno (2012), learning activities can be done individually and groups flexibly through Information and Communication Technology (ICT). In principle, the form of learning activities through ICT is structured to assist in building concepts, knowledge procedures and expressing learners' expression in learning. One of the programs (virtual laboratory) that teachers often use in the classroom is the PhET Simulation program. The combination of interactive images or animations in PhET Simulation will be easy to do when using a virtual Laboratory Students' Worksheet to assist in achieving learning achievement and it can 
replace textbooks and conventional Students' Worksheets.

Virtual laboratorypracticum Students' Worksheets by using PhET simulation media will enable students to apply the concept of physics in their daily life by practicing observations, discussions, experiments, and draw conclusions from those activities. Thus, students can find, prove, realize and apply a concept in everyday life. Therefore, senior high school physics learning is a series of teaching and learning activities which involves physics teachers as educators and senior high school students as learners who demand a change in skills, habits, attitudes, knowledge, understanding, and appreciation, so that the process can run effectively and efficiently, (Hutagalung, 2012: 39).

Based on the conditions above, the author has conducted research and development of Students' Worksheet of Virtual Laboratory Practicum on Dynamic Electricity to Improve Student Process Skills. "This research aims to generate virtual laboratoryStudents' Worksheets as media of physics learning for tenth-grade students on dynamic electricitysubject by using approach to students' science process skills. So that the quality of physics learning can be improved through the implementation of a good learning strategy and supported by the use of appropriate learning media.

Based on the background above, the following problems can be presented:

(1) How are the characteristics of virtual laboratory practicum Students' Worksheets using PhET simulation media in helping physics learning process in Senior High School? (2) How is the attractiveness and usefulness of virtual laboratory practicum Students' Worksheets using PhET simulation media in helping physics learning process in SMA?

(3) Does the use of virtual laboratory practicum Students' Worksheets effectively improve students' process skills?

The purpose of this research is to produce virtual laboratory practicum Students' Worksheetsusing PhET simulation media that fulfill the criteria of Students Worksheetswhich is interesting and useful that can be used in physics learning process, and also know the effectiveness of virtual laboratory practicumStudents Worksheets in improving the student process skill.

\section{RESEARCH METHODS}

This research used a combination of quantitative and qualitative methods (concurrentmix method) simultaneously to obtain a comprehensive analysis of the research problem as stated by Creswell (2013: 23). This research model used a research and development approach (Research and Development) used to produce a particular product and test the effectiveness of the product (Sugiyono, 2011: 409).

Research steps conducted is based on simplification and adjustment to the needs of the research which were divided into three stages of research, namely research preparation stage (preliminary study), the development and testing stage (the implementation of the research) and data process and analysis stage (final stages of the study).

The initial stage of research preparation is to conduct a field study for data collection on Physics laboratory infrastructures for practicum activities. Literature study in this research used to collect data from curriculum document and to study materials of senior high school physics. Furthermore, making the plan in accordance with the potentials and problems and the making of research instruments to reveal the needs of teachers and students, test material experts, media experts and test attractiveness, usefulness and effectiveness and make virtual laboratory practicum Students Worksheets products.

Research implementation stage was conducted by performing product development and testing or material validation, design, and media by experts to know the weakness of developed product. After the validation of the experts was performed, design revision was conducted, then instrument and the use of virtual laboratorypracticum Students Worksheets products test were conducted. The next stage of research implementation is product usage research conducted in one experimental class during learning process practicum in virtual laboratory using PhET Simulations media in State and Private Senior High Schools in Lampung Province, Indonesia. At the early stage of the learning process, students were given a matter of pre-test in the form of objective test.

Specific test methods were performed to determine the effectiveness of a product which has been developed. The research design used is Single One Shot Case Study (Sugiyono, 2011: 435). This special test was conducted on one class of experiment students of tenth-grade students in State and Private Senior High Schools in Lampung Province, Indonesia. At this stage, before conducting the learning using virtual laboratorypracticum Students Worksheets which have been developed, the students were given pre-testquestions and the students didpracticum activities according to stages in virtual laboratory practicum Students Worksheets, after the learning, the students were given post-testquestions. The test questions are organized into a description type, consisting of fifteen items of questions based on the processskill indicators. The result of pre-test and post-test 
were used to find out the achievement of learning objectives in accordance with Minimum Criteria of Mastery Learning used of 75.

Data analysis technique used the result data from the analysis of teachers and students need, those data were used to set the background and the level of product needs which have been developed. The conformity data of learning materials and design on the products were obtained from the material and design experts through expert validation test to find out the feasibility level of the product. Data of attractiveness, usefulness, and effectiveness of the product were obtained from field tests conducted directly to teachers and students. While the data level of the effectiveness of the product wasobtained through written test after the product is used. Data analysis of test result to measure the effectiveness level using criteria of science process skills of the studentin virtual laboratorypracticum Students' Worksheets of development result.

The effectiveness data of the use of virtual laboratory Students' Worksheets were assessed from the cognitive aspects of pretest and posttest values. The pretest and posttest values were tested using normality test of One-Sample Kolmogorov-Smirnov testwith SPSS whether the data were normally distributed. If sig> 0.05 then $\mathrm{H}_{0}$ is accepted $\rightarrow$ normally distributed data If $\operatorname{sig}<0,05$ then $\mathrm{H} 1$ is rejected $\rightarrow$ data are not normally distributed.

Homogeneity test was used to determinewhether the variant of the experiment group population or control group the same or not. Homogeneity test was used as a reference to determine the decision of statistical tests. The basis of decision making in the homogeneity test is:

(a). If the value is significant $>0.05$, then it is said that the variant of the experiment group and the control group are the same, (b) If the significance value is $<0.05$, then it is said that the variant of the experimental group and the control group is not the same. Normalized gain meansvalues are then classified.

Statistical hypothesis testing used in this research is the test of the equality of the two meansand the test of the difference of two means from experiment and control class. The test of the equality of the two means was performed at the initial skill (pre-test), while the test of the difference of two meanswas performed at the final skill (post-test) and n-gain data.

The effectiveness of virtual laboratoryStudents' Worksheets at product trial test stage (Pretest-posttest Control group Design) was analyzed using Independent $t$ test. While the level of product effectiveness based on the means of normalized $n$-gain values was calculated using the equation:

$$
N-\operatorname{gain}(g)=\frac{\left(s_{f}\right)-\left(s_{i}\right)}{s_{m}-S_{i}}(1)
$$

Information: $(g)=$ normalized gain, $\left(S_{f}\right)=$ posttestvalue, $\left(S_{i}\right)=$ pretestvalue $S_{m}=$ maximum value(Hake, 1999).

Normalized gain means the value is then classified as it is seen in Table 1.

Table.1: Normalized gain means value and its classification

\begin{tabular}{|l|l|l|}
\hline Normalized gain means & Classification & Effectiveness level \\
\hline$\langle g\rangle \geq 0,70$ & High & Effective \\
\hline $0,30 \leq\langle g\rangle<0,70$ & Moderate & Quite Effective \\
\hline$\langle g\rangle<0,30$ & Low & Less effective \\
\hline
\end{tabular}

The data of students' response to Virtual LaboratoryStudents' Worksheets implementation on Dynamic Electricity to improve students' science process skills were analyzed by using Linkert scale. Linkertscale is used to know the students' responses about Virtual LaboratoryStudents' Worksheets implementation in this research. In the trial of Students' Worksheet usage in small groups, the data were obtained through the questionnaire filled by the students to know the attractiveness of Students' Worksheet. The overall score of students' responses towards the implementation of Virtual laboratorypracticum Students' Worksheet of development result by using interpretation of Arikunto
(2006:195), meaning of the percentage ranges are as follows: very good $(90 \%-100 \%)$, good $(70 \%-89 \%)$, good enough, (50\%-69\%), poor $(0 \%-49 \%)$.

\section{RESULT AND DISCUSSION}

The main result of the development research conducted in State and Private Senior High Schools in Lampung Province, Indonesia is that the development of virtual laboratory practicum students' worksheet on dynamic electricity effectively improves the science process skills of the students. Practicum Students' Worksheet of virtual laboratorywas used to teach the physics concept of dynamic electricity. 


\subsection{Potential and Problems}

Based on the results of the research with the observation and questionnaire methods towards physics teachers in Senior High School in Lampung Province, Indonesia the results obtained were measured by analyzing the percentage of physics laboratory use for learning, especially on dynamic electricity subject. The analysis which was conducted on the completeness of laboratory facilities, supporting facilities for practicum activities, especially on the availability of students' worksheet and the need for learning media, and the usefulness of computer laboratory especially for Virtual Laboratory practicum learning.

In state senior high schools in Lampung Province, Indonesiathe potential and problems related to students' worksheet have been known. The potentials of the school that is the place of study are the availability of computer laboratories and the percentage of teachers 'ability to operate the computer is $80 \%$, and the percentage of teachers' need for alternative learning media such as PhET Simulationisalso $80 \%$. Most students already have a personal laptop. Problems which are found arethat most laboratory facilities in senior high school in Lampung Province, Indonesiaare very poor, both teachers and students have difficulty in carrying out practicum activities and mostly, thestudents wanted practicum activities because practicum activities are rarely done during the learning process.

In addition, the tools and practicum materials available in the school laboratory to conduct dynamic electricity experiments are incomplete, and students tend to be afraid of conducting real experiments on electricity.

After the potential and problems can be demonstrated factually, the next step is to gather information. Information is obtained through literature study by reading directly the books, journals, and articles accessed via the internet. This study is also aimed to collect concepts and materials from the various literature required in designing products that will be developed. The main information that must be known is the procedure in preparing practicum Students' Worksheet, learning models, learning media needed, and difficult subject materials.

\subsection{Product Result Which is Developed}

The product which is developed is in the form of Students Worksheet for practicum activity virtually using PhET Simulations media aid which can be operated off line using computer/laptop after the media is installed. PhET Simulations operations also require Java Runtime Environment or JRE applications. In PhET Simulations, there are drawings of tools for practicum activities and a screen which is available for practicing virtual practicum in visual form (The PhET Team, 2015).

Preparation of Students' Worksheet of Virtual laboratorypracticum and the production of this product refers to the materials that must be mastered by the students both in theory and practice. The materials used in this Students' Worksheet are Dynamic Electricity of Ohm's Law, Series, and Parallel Resistor Circuits, and Kirchhoff's Law I. The Students' Worksheet is packaged in the form of guidance when doing practicum activities consisting of front cover which contains the title of Students' Worksheet, main subject and author's name. The front cover view is as in Picture 1 shown below.

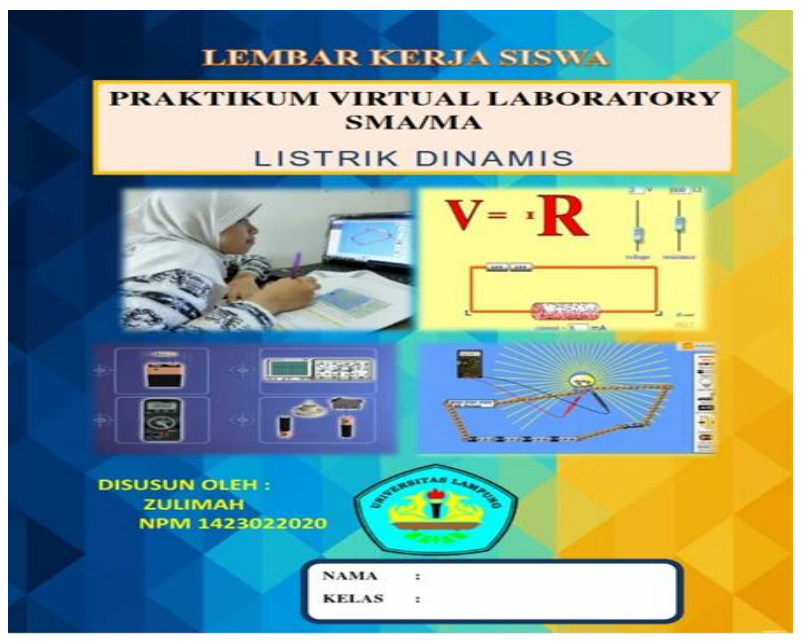

Picture.1: Students'Worksheet Cover

Inside the Students' Worksheet, there arepreface, table of contents, competency standards, basic competencies, indicators, introductions, and instructions on the use of Students' Worksheet. In each practicum activity, practicum title, practicum purpose, theoretical basis, predictability and hypothesis making ability, tools and materials are used, how to work, tables of observations, columns to graph and conclusions are all presented.

Worksheets which are developed in accordance with indicators of the ability of the process of science students, and in the Students Worksheet, there is also an example of the problem/question along with a description of the answers and at the end of practicum activities, the questions to test the concept comprehension as student competence tests.

\subsection{Design Validation Result}

The product result is in the form of Students Worksheet that has been developed andthe feasibility has been further tested to know the attractiveness, usefulness, and effectiveness of the products to the validator which consists of material and design experts who are master 
program lecturers of physics education of University of Lampung, Indonesia. Who are experts in education and science. Based on the assessment of material/learning design experts using the criteria of conformity/validity and product revision, it can be seen that the Dynamic Electricity material in the Students' Worksheet of Virtual Laboratory Practicum is quite valid as one learning resource, with a percentage of $71.43 \%$.

The analysis of the assessment of three lecturers who are expert in media stated that the media of Students' Worksheet ofVirtual LaboratoryPracticum is interesting and useful in learning with an average percentage of $85.42 \%$.The test of individual experts and small groups was validated by 2 expert lecturers, to evaluate the quality of attractiveness, easiness and benefit and physical quality of Virtual LaboratoryPraktikumStudents' Worksheet. From the questionnaire analysis, it is obtained that the average percentage rating of $77.78 \%$.

\subsection{Media Expert Test Result}

From the assessment analysis by three media experts who are master program lecturers of education of the University of Lampung, it can be obtained that Virtual Laboratorypracticum Students' Worksheet is attractive and useful in learning on dynamic electricity material with a percentage of $85,42 \%$. There are things according to some suggestions and inputs from the media experts to improve, they are (1) the color of the Students' Worksheet'scover, do not use many colors, (2) the font does not need to be variative, so it must be reorganizedand, (3) the letter size and the color of the letters also should be reseted.

\subsection{Small Groups and Individual Experts Test Result}

Small groups and individual experts test resultswere validated by 2 expert lecturers to evaluate the aspect of attractiveness and usefulness as well as the physic quality of the Students' Worksheet of Virtual Laboratorypracticum. The quality of attractiveness and usefulness of the product are seen from the result of validation questionnaire analysis of test result by both experts: Expert 1 with the percentage average of 83,33 withattractive and usefulness categoriesand expert 2 with the percentage average of 72,22 and also with attractive and usefulness categories

The small groups test took samples from Physics teachers who taught in State and Private Senior High Schools in Lampung Province, Indonesia. The data related to the feasibility of using Virtual Laboratorypracticum Students' Worksheet are taken by using the questionnaire in the form of questions with four alternative answers from numbers 1 to number 4 . From the results of effectiveness and attractiveness questionnaire on the individual test $(n=6)$, teachers from Senior High School Lampung Province, Indonesiastated that it is effective $(83 \%)$ and very interesting $(87 \%)$. Teachers from PrivateSenior High School Lampung Province, Indonesia stated that it is effective $(84 \%)$ and very interesting (89\%).

The result of the analysis towards the questionnaires given to the students after implementing the learning process using virtual laboratorypracticum Students' Worksheet showed that virtual laboratorypracticum Students' Worksheet is interesting and useful for the students in both schools with percentage of $86.42 \%$ forstate senior high school and $84.67 \%$ for private senior high school in Lampung, Indonesia. Therefore, in general,virtual laboratorypracticum Students' Worksheet for learning has been interesting, effective and useful, so it is worth to use, to develop and to utilize in the field.

\subsection{Product Use Trial}

Virtual Laboratorypracticum Students' Worksheet in improving science process skills and scientific attitude of the students in this research is measured from the assessment of each component of practicum activities in accordance with the indicators of students' science process skills as well as assessment in terms of mastery of the concept of the material on each learning and achievement of the purpose of practicum activities.

The step taken by the researcher to determine the effectiveness of the use of virtual laboratorypracticum Students' Worksheetis by measuring the ability of students using a set of tests. Begin by giving a pre-test, in accordance with the indicators made. The questions prediction of test instrument has been made and has been tested in a higher class at State Senior High School Province Lampung, Indonesia which is not used as experiment class.

Product trial was conducted in state and private senior high schools in Lampung Province, Indonesia using two classes namely experiment and control class. The experiment class in the learning conducts practicum activities using virtual laboratory practicum Students' Worksheet results from the development.

The effectiveness level can be determined from the higher post-testmeans value compared to the pre-test value in the experiment class for both schools. Themeans of $N$-gain (g) value is 0.80 for state senior high school and 0.75 for private senior high schoolwith the result of gain calculation which is then interpreted. If the normalized gain means is $(\mathrm{g}) \geq 0.70$, then it is included in the high classification with "effective" level. It means that 
the learning using virtual laboratory practicum Students'

Worksheet can be said to be effective. The analysis of the pre-test and post-test values in the experiment and control classes is shown in Table 2 below.

Table.2: The means value of experiment and control class on field test

\begin{tabular}{lcccccc}
\hline \multirow{2}{*}{ School Name } & \multicolumn{3}{c}{ Experiment Class } & \multicolumn{3}{c}{ Control Class } \\
\cline { 2 - 7 } & Pre-test & Post-test & N-gain & Pre-test & Post-test & N-gain \\
\hline $\begin{array}{l}\text { State Senior } \\
\text { High School }\end{array}$ & $54,9 \pm 8,070$ & $88,9 \pm 5,192$ & 0,80 & $63,4 \pm 8,750$ & $78,1 \pm 7,952$ & 0,40 \\
\hline $\begin{array}{l}\text { Private Senior } \\
\text { High School }\end{array}$ & $44,1 \pm 8,302$ & $82,2 \pm 4,763$ & 0,75 & $54,3 \pm 10,141$ & $75,2 \pm 11,359$ & 0,53 \\
\hline
\end{tabular}

Based on the results of product trial, it is found that virtual laboratory practicum Students' Worksheet isvery attractive, easy to use and useful in learning, especially on dynamic electricity materials.

\subsection{Pre-testResult Data Analysis}

\subsubsection{Normality Test Result}

The result of Kolmogorov-Smirnov normality test showed that the pre-test variable in experiment class in State Senior High School has significance value (Sig.) of 0,231 and control class of 0,319 . Both values are (Sig.) > 0.05 so it can be concluded that the pre-test values in both classes have normally distributed data. Normality test was also conducted in experiment and control class at Private Senior High School inLampung Province,indonesiawhich indicated that pre-test variable in experiment class has significance value of (Sig.) 0,491 and control class of 0,276 . Both values are (Sig.) $>0.05$, so it can be concluded that the pre-test values in both classes have normally distributed data.

\subsubsection{Homogeneity Test Result}

After conducting Normality Test, normally distributed data are obtained, then the next test is homogeneity test of both groups. Homogeneity tests are needed to find out whether the data have been obtained from samples which have the same or homogeneous variant. Homogeneity test results are seen on the value (Sig.) which shows the value of 0.001 . Because the value of Sig is $0.001<0.05$, it can be concluded that the pre-test data of both classes are not homogeneous. The next stage is to test the pre-test data with the two-sided equality test to see the process skills and the scientific attitude between the experiment and control class whether equal. The pre-test data were analyzed using the t-test (independent sample t-test). Because the value of Sig is (1-tailed) $=0,246>0,05$, for State Senior High
School and Sig value of (1-tailed) $=0.356>0.05$, for Private Senior High School in Lampung Province, Indonesia so that $\mathrm{H}_{0}$ is accepted, it can be concluded that there is no difference of pre-test means value for the experiment and control class.

\subsection{Post-testResult Data Analysis}

The final ability test (post-test) data was obtained from the result of the test after the completion of learning using virtual laboratory practicum Students' Worksheet based on the process skill and scientific attitude of the students in the experiment class. The post-testvalue of the experiment class is greater than the control class in the two schools. The means value of the experiment class is 88.93 while the control class is 78.15 in the State Senior High School and the means of experiment class is 82.26 while the control class is 75.17 in the Private Senior High School in Lampung Province, Indonesia.

The researcherconducted the post-test data normality test in the experiment and control class, in both schools. For both classes on both schools, the sig value (2-tailed) or probability value is $\geq 0.05$, so $\mathrm{H}_{0}$ is acceptedwhich means that the data come from the normally distributed data.

Based on the homogeneity test of Post-test data from the two schools, it showed that the significance value is 0,100 and 0,250 . Because the sig value is. $\geq 0.05$, so $\mathrm{H}_{0}$ is accepted, which means that both classes have the same or homogeneous variants. After the normality and homogeneity test, the parametric hypothesis was tested to see the difference of Post-test data means, by using t-test (Independent Sample t-test) with the assumption of two homogeneous variants (Equal Variance Assumed). Sig value $(2$-tailed $)=0,000$ indicated that the value of $\mathrm{Sig}$ is (2-tailed) $<0.05$, so $\mathrm{H}_{0}$ is rejected and $\mathrm{H} 1$ is accepted, it can be concluded that there is a significant difference between the means value of the students' process skills in experiment class of the experimental class the means value of control class..

The researcher then conducted a t-test or the difference test in the experiment class. T-test is performed 
to know the difference of learning result before and after the learning using virtual laboratorypracticum Students' Worksheet based on science process skills. The test results showed that the sig. (2-tailed) value for both Pretest and Post-testvalues of learning in the experiment class using the Virtual Laboratorypracticum Students' Worksheet of 0,000 indicated the value of Sig. of (2tailed) $<0,05$, which means that $\mathrm{H}_{0}$ is rejected and $\mathrm{H} 1$ is accepted. The data were tested using Paired Sample TTest, based on the statistical result, there was a significant difference of student learning result before and after the learning process which used Virtual Laboratory practicum Students' Worksheet.

Analysis of effectiveness test of virtual laboratorypracticum Students' Worksheet from post-test data usedthe normalized $\mathrm{N}$-gain test in the experiment class. With product effectiveness level based on the meansof normalized gain value was calculated if $N$-gain is $(\mathrm{g}) \geq 0.70$ including in the high classification and effectiveness level including effective, (Hake, 1999:66).
The pre-test and the post-test value of the experiment class are then calculated on the means of $\mathrm{N}$ Gain value $(\mathrm{g})$. The results obtained are the value of $(\mathrm{g})=$ 0.8 including high criteria for Senior High School and value of $(\mathrm{g})=0.75$ high criteria also for private Senior High School in Lampung Province. Therefore, learning which uses virtual laboratorypracticum Students Worksheet with the help of PhET Simulations media effectively improve learning outcomes. Analysis of effectiveness test of virtual laboratorypracticum Students Worksheet in improving student process skill involves cognitive/intellectual, manual and social skills. The approach to the science process skill in question is the skill that governs the scientific method, including the skill of predicting process, hypothesis, observation, interpretation, and communication. The process skills which were developed and observed from the beginning based on pre-test/post-testquestions groupings were in accordancewith the process skill indicators, as they are shown

Table3.

Table.3: N-Gainmeans of Science Process Skills of State Senior High School Students

\begin{tabular}{|c|c|c|c|c|c|c|}
\hline \multirow{2}{*}{$\begin{array}{l}\text { Science Process } \\
\text { Skills Indicators }\end{array}$} & \multicolumn{3}{|c|}{ Experiment Class } & \multicolumn{3}{|c|}{ Control Class } \\
\hline & $\begin{array}{l}N \text {-gain } \\
\text { (g) }\end{array}$ & Criteria & $\begin{array}{c}\text { Effectiveness } \\
\text { Level }\end{array}$ & $\begin{array}{l}N \text {-gain } \\
\quad(g)\end{array}$ & Criteria & $\begin{array}{c}\text { Effectiveness } \\
\text { Level }\end{array}$ \\
\hline Predicting & 0,9 & High & Effective & 0,7 & High & Effective \\
\hline Hypothesizing & 0,9 & High & Effective & 0,3 & Moderate & Quite Effective \\
\hline Observing & 0,8 & High & Effective & 0,4 & Moderate & Quite Effective \\
\hline Interpreting & 0,7 & High & Effective & 0,4 & Moderate & Quite Effective \\
\hline Communicating & 0,6 & Moderate & $\begin{array}{c}\text { Quite } \\
\text { Effective }\end{array}$ & 0,3 & Moderate & Quite Effective \\
\hline$N$-Gain $(g)$ means & 0,7 & High & Effective & 0,4 & Moderate & Quite Effective \\
\hline
\end{tabular}


The average achievement of the students' science process skills in the experiment class at Private Senior High School Lampung Province, Indonesia with $N$-Gain $(g)$ of 0.7 is categorized as high (effective) compared to the control class. The differences in the achievement of the value of the science process skills can occur due to different approaches applied during the learning process.

Thus, it can be concluded that the science process skills of students whose learning with the practicum model is better than students who are taught by the talking model. This is because the science process skills are trained to the students in line with the implementation of the learning stages according to the process skill indicators in the virtual laboratory practicum Students' Worksheet. The results of this researchobtained are supported by the results of previous research conducted by Aktamiset al. (2008), who stated that learning by practicum model can improve students' process skill. One of the indicators of students' science process skills results is shown in Picture 2 below.

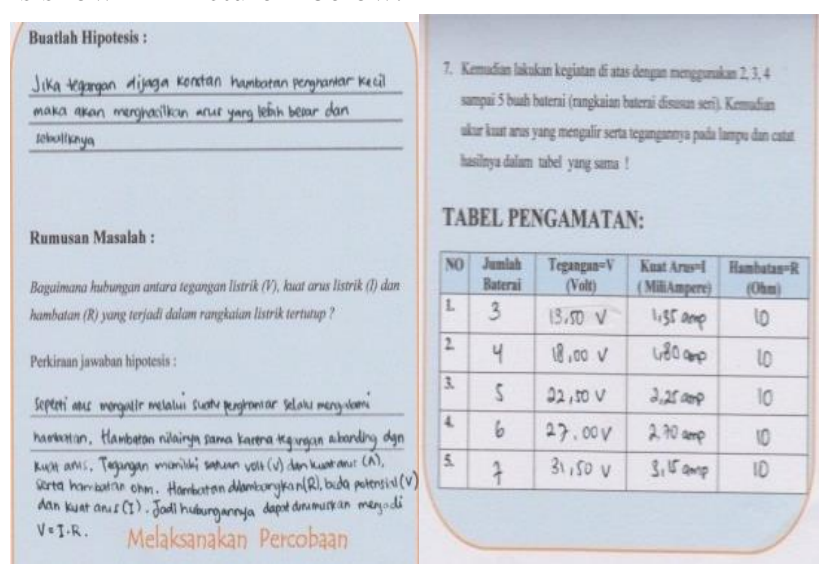

Picture.2: The results of Science Process Skills of the Students

Science process skills of the student can also be measured from the increase of the cognitive value of concept comprehension at every process of practicum activities using virtual laboratory practicum Students' Worksheet based on the result of cognitive means value in both schools of 89,33 and 86,67 , which

The analysis of the attractiveness and usefulness test of virtual laboratory practicum Students' Worksheet from the expert questionnaire test value is limited, converted into quality statement indicating that virtual laboratory practicum Students' Worksheet is attractive and useful for the students with means percentage of $77,78 \%$ which means that it is categorizedasattractive and useful criteria. While in the large group test with the entire student population in the experiment class as many as 30 students in State Senior High School and 38 students in Private High School in Lampung Province,
Indonesia. After the learning process using virtual laboratory practicum Students' Worksheetis completed, students were given a questionnaire about the response to the application of the product. The result of questionnaire analysis showed that most, virtual laboratory practicum Students' Worksheetare attractive for the students in both schools with a percentageof $86,42 \%$ in State Senior High School and $84,67 \%$ at Private Senior High School in Lampung Province, Indonesia.

\section{CONCLUSION}

Based on the results and discussions, it can be concluded that: (1) virtual laboratory practicum Students' Worksheet on the physics subject of dynamic electricity concept with approach of process skills and scientific attitude of students who have attractive and usefulness characteristics to improve student learning outcomes that contain steps of virtual practicum activity, including aspects of assessment and indicators of students' science process skills, as well as concept comprehension test as a competency test equipped with instructions on the use of virtual laboratory practicum Students' Worksheet is produced. (2) virtual laboratory practicum Students' Worksheet produced has been validated by material and media experts and has been tested by theoretical theory with quality: attractive and very useful for students in the learning process to improve the skills of the students process based on the improvement of student learning outcomes seen from the value of pre-test and post-test on field test towards tenth grade students of State Senior High School and tenth grade student of Private Senior High School in Lampung Province, Indonesia in School Year 2016/2017. (3) The effectiveness of virtual laboratory practicum Students' Worksheet in improving the students' process skill has been validated by experts and tested according to theories with the quality and it has been stated as very effective to use in the learning process. Improvement of students'science process skills is seen based on the improvement of students' cognitive value on each comprehension test of Ohm Law's material concept, series and parallel circuits, and Kirchhoff's Law I.

\section{REFERENCES}

[1]Aly, A dan Rahma, E. (2011).MKDU ;Ilmu Alamiah Dasar.Jakarta : Bumi Aksara

[2]Aktamis, Hilal, Ergin, Omer. (2008). The Effect of Science Process Skills Education on Students' Scientific Creativity, Science Attitudes, and Academic Achievements. Journal Article Turkey. Asia-Pacific Forum onScience Learning and Teaching, vol 9 no1.Web site : http//www.ied.edu.hk/apfset 
[3]Arikunto, Suharsimi. (2006). Prosedur Penelitian Suatu Pendekatan Praktek. Jakarta: Rineka Cipta

[4]Creswell, J.W. (2013).Research Design: Pendekatan Kualitatif, Kuantitatif dan Mixed. Terjemahan Fawaid, A. Yogyakarta: Pustaka Pelajar

[5]Finkelstein,N.,Adams,W.,Keller, C., Kohl,P., Perkins, K., Podolefsky, N., Reid,S., \& Le Master,R.(2005). When Learning about the Real World is Better Done Virtually: A Study of Substituting Computer Simulations for Laboratory Equipment. Physical Review Special Topics - Physics Education Research,Vol.1,No.010103

[6]Hake, R.R. (1999).Analyzing Change/Gain Scores.Aera-D - American Educational Research Association's Division D, Measure-ment and Research Methodology. http://www.physics.indiana.edu/ hake

[7]Hofstein, A.,\& Lunetta, V,N. (2003). The Laboratory in Science Education : Foundations for The TwentyFirst Century. Science Education, 88 (1), 28-54.

[8]Hutagalung, Andar.(2012). Pengaruh Model Pembelajaran Peningkatan Kemampuan Berpikir Terhadap Hasil Belajar Pada Materi Pokok Besarandan Pengukuran Di Kelas X SMAN 1 BALIGE. Jurnal Online Pendidikan Fisika Volume1 No1 (e-ISSN:2301-7651)Medan. http://dikfispasca.org/andar-m-hutagalung.

[9]Imron,M. (2012). Memanfaatkanlab Virtual (Online) : (http://www.mazguru.wordpres.com/2012/04/19/ayom anfaatkanlaboratorium virtual, diakses 12 Oktober 2014).

[10]Sanjaya,W. (2009). Strategi Pembelajaran Berorientasi Standar Proses Pendidikan. Kencana Prenada Media Group, Jakarta.

[11]Sugiyono. (2011). Metodologi Penelitian Pendidikan. Bandung: Alfabeta.

[12]Sutrisno.(2012). Kreatif Mengembangkan Aktivitas Pembelajaran Berbasis TIK, Jakarta :Referensi

[13]The PhETTeam. (2015). PhET (Intective Simulations). (Online):http://www.PhET. colorado.edu/in/. diakses3 Maret2015).

[14]West, LeoH.R.(1985).Concept Mapping. Chicago: Chicago University Press.

[15]Zacharia,C.Z.,Olympiou, G. and Papaevripidou, M.(2008). Effects of Experimenting with Physical and Virtual Manipulativeson Students'Conceptual Understanding in Heatand Temperature. 